\title{
水害リスク情報の表現方法が 水害リスク認知の促進に及ぼす影響について
}

\author{
柿本 竜治 1 - 榎村 康史 2 \\ 1正会員 熊本大学 大学院自然科学研究科（干860-8555 熊本市黒髪2目39-1） \\ E-mail: kakimoto@gpo.kumamoto-u.ac.jp \\ 2正会員 北海道開発局 帯広開発建設部（干080-8585 北海道帯広市西4条南8丁目） \\ E-mail: enomura-y22aa@hkd.mlit.go.jp
}

\begin{abstract}
本研究では, 水害リスクの認知や洪水への備えを促す水害リスク情報の表現方法を検討することを目的 としている，そこで，まず，水害リスクの高い地域を対象に水害に関する意識調査を行い，「水害への意 識」と「洪水への備え」に関する因果構造分析と洪水ハザードマップの評価を行った。それらの結果を考 慮して，「洪水ハザードマップ」，「30年確率表記」および「リスクのモノサシ」の3種類の水害リスク 情報を作成し，住民に提示した。その結果，各提示情報の特性に応じて水害リスク認知や備えが促される ことが分かった．さらに，各表現方法の特徵が活かすために，「洪水ハザードマップ」に「30年確率表 記」と「リスクのモノサシ」を付加することで, 洪水ハザードマップの理解度と信頼性が向上した。
\end{abstract}

Key Words : flood risk, hazard map, preparedness, knowledge transfer, risk communication

\section{1. はじめに}

近年，ハード対策のみによる防災の限界が認識され， ソフト的な対策への取り組みが盛んになってきている. 洪水ハザードマップの住民への公開・配布は, 重要なソ フト施策の一つに位置付けられている。一方，住民は提 供された洪水ハザードマップの情報を正しく理解し，自 身が住む地域のリスクに備えることが求められている. しかし，かつて水害常襲地域でハード対策の効果により， 長期間水害がない状況に慣れた住民にとっては，洪水八 ザードマップの情報を見ても，自身が住む地域のリスク を軽視してしまう傾向にある，また，洪水ハザードマッ プの情報を見て, 洪水ハザードマップで想定されている 災害しか起こらないと認識してしまう恐れや，洪水ハザ 一ドマップで想定されている浸水深が比較的浅いことに 安心感を覚えてしまう恐れなども指摘されている ${ }^{1)}$.つ まり，現在の洪水ハザードマップでは，行政が意図した 危険性の認識を住民に与えることが出来ていない可能性 がある，そこで，住民が受け入れやすく，正しく理解で きる水害リスク情報の表現方法が求められている.

災害リスクの情報に関する研究として, 災害リスクコ ミュニケーションのあり方の考察 ${ }^{213)}$ ，洪水ハザードマ ップを見た住民のリスク認知についての考察4,5,9などが ある．また，住民の洪水ハザードマップの認知・受容に
関する問題として，正常化の偏見や災害イメージの固定 化，浸水シナリオの前提条件に関する認識の欠如などが あることを指摘し，精緻なマップと粗なマップを比較し， 災害イメージの固定化が小さくなることや情報取得態度 の向上などの点からが粗なマップの方がメリットが大き いとし, 洪水ハザードマップの公表効果と問題点を整理 し, 効果的な活用法を検証した研究 ךもある. 住民に提 示する情報として洪水ハザードマップが最も有効である ことを前提とし, 情報の記載内容について考察を行って いる研究もある ${ }^{8), 9}$. 一方, 天王らは, 水害リスクの現 状評価を行い，水害リスク認知と自主防災行動等とのズ レ，すなわち，自主防災行動における認知不協和の現状 を把握し，個別の自主防災行動ごとの課題の明確化を行 っている ${ }^{10)}$. その上で，自主防災行動モデルを作成し， 自主防災行動促進策の検討を行っている ${ }^{11)}$.このように 災害リスク情報とリスク認知の関係を分析したものや災 害リスク認知の促進を目指した研究は，これまでにもい つくかなされている。しかしながら，災害リスク情報の 表現方法によるリスク認知や災害への備えの促進効果の 違いを比較検討している研究は少ない.

そこで, 本研究では, 水害リスクの高い地域に居住す る住民のリスク認知や洪水への備えを促す水害リスクの 表現方法を検討する. そのために，本研究では，まず， 事前調査として水害への意識に関するアンケートを行い, 
水害への意識と対策の現状を把握する. そして，そのデ 一夕を用いて洪水への備えの因果構造をモデル化し, 水 害リスク認知の促進と洪水への備えの関係を明らかにす る. それと同時に，住民による洪水ハザードマップの評 価を行い，それと因果構造分析の結果を併せて考慮し， 洪水ハザードマップに記載されている情報を他の表現で 記述する．そして，表現方法の異なる水害情報を住民に 提示し, 地域の水害や備えに対する意識の変化を考察し, 洪水ハザードマップに付加する情報を検討する.

\section{2. アンケート調査の概要}

\section{(1) 対象地域の概要}

アンケート調査の対象地域は, 図-1に示寸熊本県人吉 市内の温泉町・下林2区・下林仮屋地区である.この地 域は，球磨川と万江川の合流地点付近にあり，表-1に示 すように過去に何度も水害に遭っている洪水常襲地域で ある. 近年も平成16 18年に台風や大雨による内水汇濫 が発生し，一部地域に避難锥告が出されている. 球磨川 と対象地域内の河川との合流点に，水門やポンプ施設の 整備が近年進められているが，球磨川の水位が高くなる と支流が汇濫する危険性は避けられない，球磨川の堤防 に対して対象地域の標高がきわめて低く,また，球磨川 と万江川の合流点方向に向かって標高が低くなっている ため, 球磨川や支流の河川が汇濫した場合, 水が溜まり や寸い地形となっている.

現在，球磨川は80年に1度起こる規模の降雨量を想定 した整備が進められている. 球磨川の人吉市地点におけ る基本高水流量は $7,000 \mathrm{~m}^{3} /$ 秒であり, 河道一の配分流量 $4,000 \mathrm{~m}^{3} /$ 秒， 洪水調節施設による調節流量 $3,000 \mathrm{~m}^{3} /$ 秒と 計画されている ${ }^{12}$. なお，洪水調節施設による調節流量 のうち, $1,300 \mathrm{~m}^{3} /$ 秒は球磨川上流の市房ダムで, 残りの $1,700 \mathrm{~m}^{3}$ /秒は球磨川支流の川辺川ダムによって計画され ていたが，川辺川ダム建設は現在中止されている. 人吉 市地点での球磨川の流下能力は現在 $3,600 \mathrm{~m}^{3}$ /秒であり, 対象地域は水害に対して危険な地域である.

\section{(2) アンケート調査の概要}

水害リスク情報の表現方法の違いで, 住民の水害リス
クの認知や洪水への備えの意識にどのような差が生じる か調べるために対象地域の中から無作為に150世帯を抽 出し, 訪問留置き後日回収によるアンケート調査を行っ た．アンケート調查は2010年10月と12月に実施した。 ア ンケート項目の概要を表-2に示寸.

事前調查として，表-2の「居住状況」，「水害への意 識」，および「洪水への備え」に関する各項目と洪水八 ザードマップの評価についてアンケートを行った．事前 アンケート調査の回収世帯数は 150 世帯であった.

事前調查結果を考慮した上で，水害リスク情報を後述 する「30年確率表記」と「リスクのモノサシ」で表現し た. そして, 調查対象世帯を 3 グループに分割し, グル

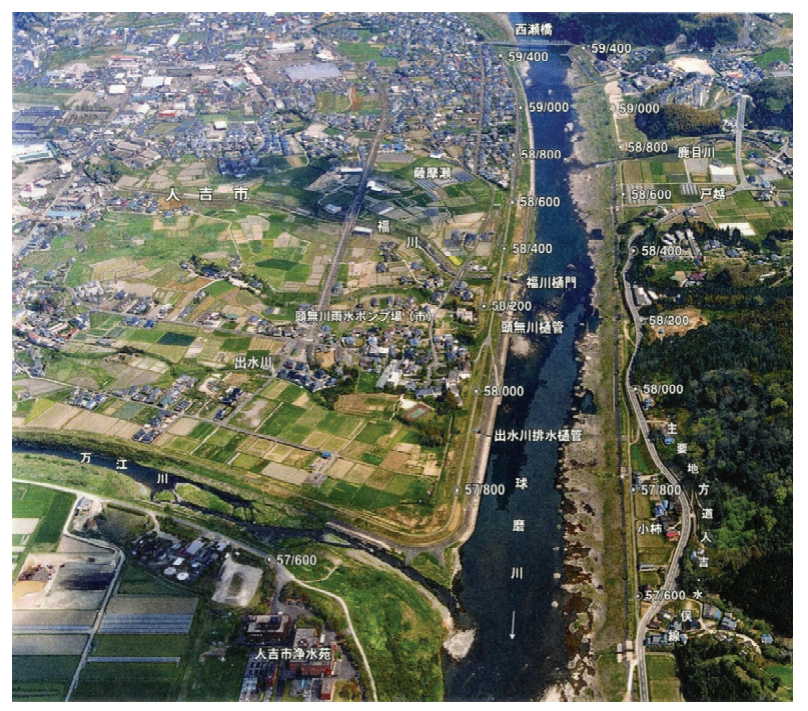

図-1 対象地域の航空写真（提供 : 熊本県）

表-1 球磨川流域の過去の被害状況

\begin{tabular}{|c|c|c|c|c|}
\hline \multirow[b]{2}{*}{ 発生年月 } & \multicolumn{3}{|c|}{ 被害の概要(戸) } & \multirow{2}{*}{$\begin{array}{c}\text { 人吉地点で } \\
\text { の最大流量 } \\
\left(\mathrm{m}^{3} / \text { 秒 }\right)\end{array}$} \\
\hline & $\begin{array}{l}\text { 家屋の損 } \\
\text { 壊·流出 }\end{array}$ & $\begin{array}{l}\text { 床上 } \\
\text { 浸水 }\end{array}$ & $\begin{array}{l}\text { 床下 } \\
\text { 浸水 }\end{array}$ & \\
\hline 昭和 38 年 8 月 & 281 & 1,185 & 3,430 & 約 3,000 \\
\hline 昭和 40 年 7 月 & 1,281 & 2,751 & 10,074 & 約 5,700 \\
\hline 昭和 46 年 8 月 & 209 & 1,332 & 1,315 & 約 5,300 \\
\hline 昭和 47 年 7 月 & 64 & 2,447 & 12,164 & 約 4,100 \\
\hline 昭和 57 年 7 月 & 47 & 1,113 & 4,044 & 約 5,500 \\
\hline 平成 16 年 8 月 & - & 13 & 36 & 約 4,300 \\
\hline 平成 17 年 9 月 & - & 46 & 73 & 約 4,500 \\
\hline 平成 18 年 7 月 & - & 41 & 39 & 約 3,600 \\
\hline
\end{tabular}

表-2 アンケート項目の概要

\begin{tabular}{|c|c|c|}
\hline 居住状況 & 水害への意識 & 水害への備え \\
\hline $\begin{array}{l}\text { 年齢 } \\
\text { 居住年数 } \\
\text { 居住人数 } \\
\text { 建物の構造（木造・鉄管 }) \\
\text { 建物の階数 }\end{array}$ & $\begin{array}{l}\text { 洪水ハザードマップについて } \\
\text { 洪水ハザードマップを見てどう感じたか } \\
\text { 球磨川の整備状況について } \\
\text { 球磨川の整備計画の水準について } \\
\text { 球磨川の30年以内氾濫確率について } \\
\text { 想定浸水深について } \\
\text { 水害に対する町内の安全性について } \\
\text { 水害時の自宅の安全性について }\end{array}$ & $\begin{array}{l}\text { 避難経路の検討状況 } \\
\text { 非常持出品の準備状況 } \\
\text { 水害保険加入の有無 } \\
\text { 洪水に備えた近所との関係 } \\
\text { 建築方法の工夫 } \\
\text { 家具の配置の工夫 } \\
\text { 大雨時の情報入手方法 }\end{array}$ \\
\hline
\end{tabular}




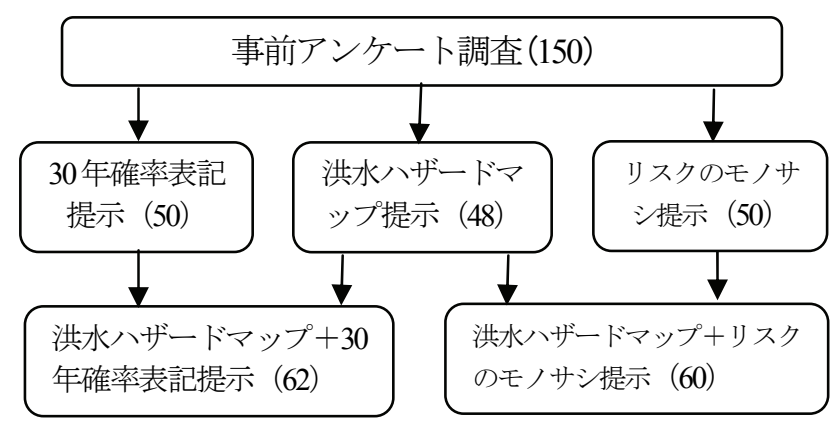

図-2 アンケート調査全体の流れ

ープ毎に異なった表現の水害リスク情報を提供し，再度 「水害への意識」および「洪水への備え」に関する項目 について意識調査を行った. その際の回収世帯数は, 148 世帯であった。

さらに, 「30 年確率表記」で水害リスク情報を提供 した世帯と「洪水ハザードマップ」で水害リスク情報を 提供した世帯の半数に，「洪水ハザードマップ」に「30 年確率表記」を付加した水害リスク情報を提供した。一 方，「リスクのモノサシ」で水害リスク情報を提供した 世帯と「洪水八ザードマップ」で水害リスク情報を提供 した残り半数の世帯に，「洪水ハザードマップ」に「リ スクのモノサシ」を付加した水害リスク情報を提供した. そして，「提供情報の理解」および「提供情報の信頼 性」について意識調查を行った．最終的な回収世帯数は, 122 世帯であった. 図-2 にアンケート調查全体の流れを 示寸.

\section{3. 事前アンケート調査結果の概要}

\section{（1）回答者の属性分布}

事前アンケート調査回答者の属性分布を図-3に示寸. 回答者の7割近くが60代以上であり, また, 半数以上が1 人もしくは 2 人暮らしの世帯である. 対象地域に 20 年以 上居住している世帯は $52 \%$ \%ある. 表-1に示したように, 対象地域は昭和 40 年と昭和 57 年に洪水の甚大な被害を受 けており，回答者の約半数が水害を経験している.

人吉市では，2006年に洪水ハザードマップを配布して いるが，2010年6月に新しい洪水ハザードマップを配布 し，説明会を開催している. 図-4に対象地域での洪水八 ザードマップの認知度を示す. 約6割が見たことがある と回答しているが，内容まで理解しているのは約4割弱 である．次に，洪水ハザードマップ上での想定浸水深別 アンケート回答者の分布と回答者自身の想定浸水深の分 布を表-3に示す．想定浸水深が $2 \mathrm{~m}$ 以上 $5 \mathrm{~m}$ 未満の地域に 約70\%の世帯が居住しており，図-3に示すようにその多 くは低層の木造家屋である．また，八ザードマップ上で は対象地域のすべての世帯が浸水するが，半数以上の 84 世帯が自身の家屋は浸水しないと回答している．洪水八

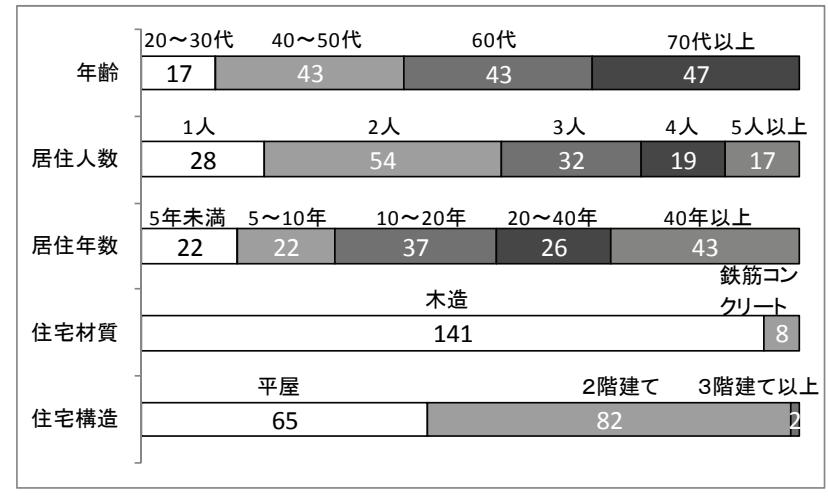

図-3 アンケート回答者の属性分布

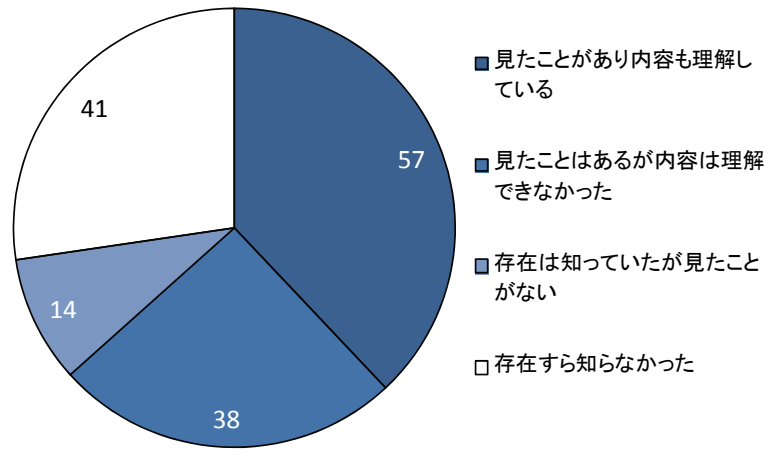

図-4 対象地域での洪水ハザードマップの認知度

表-3 ハザードマップと回答者の想定浸水深

アンケート回答者の想定浸水深

\begin{tabular}{|c|c|c|c|c|c|c|c|c|}
\hline 弅 & & 浸水しない & $0.5 \mathrm{~m}$ 以下 & $0.5-1.0 \mathrm{~m}$ & $1.0-2.0 \mathrm{~m}$ & $2.0-5.0 \mathrm{~m}$ & $5.0 \mathrm{~m}$ 以上 & 計 \\
\hline 1 & 浸水しない & 0 & 0 & 0 & 0 & 0 & 0 & 0 \\
\hline 字 & $0.5 \mathrm{~m}$ 以下 & 4 & 0 & 0 & 0 & 0 & 0 & 4 \\
\hline プ & $0.5-1.0 \mathrm{~m}$ & 5 & 2 & 1 & 0 & 0 & 0 & 8 \\
\hline 想 & $1.0-2.0 \mathrm{~m}$ & 22 & 5 & 5 & 2 & 1 & 0 & 35 \\
\hline 正 & $2.0-5.0 \mathrm{~m}$ & 53 & 27 & 16 & 6 & 1 & 0 & 103 \\
\hline 水 & 5.0m以上 & 0 & 0 & 0 & 0 & 0 & 0 & 0 \\
\hline 深 & 計 & 84 & 34 & 22 & 8 & 2 & 0 & 150 \\
\hline
\end{tabular}

ザードマップ上の想定浸水深と回答者自身の想定浸水深 の関係は，対角線の左下側の組み合わせに回答が集中し ており，洪水に対し危険な地域に居住しているにも関わ らず，大部分の世帯が自身の居住地域を安全と考えてお り，正常化の偏見があることが分かる.

\section{（2）水害への意識と対策の現状}

対象地域を流れる球磨川の整備状況に関する知識と洪 水発生に対する意識を図-5に示す，球磨川は 80 年に1度 起こる規模の降雨量を想定した整備が進められており, 対象地域付近の基本高水流量 $7,000 \mathrm{~m}^{3}$ /秒に対し，現在の 処理能力はダムと合わせて $4,900 \mathrm{~m}^{3} /$ 秒である。このよう な整備状況にあるが，球磨川の河川整備は「完了してい る」もしくは「もうすぐ完了する」と半数以上が回答し ている. 球磨川の河川整備水準の想定降雨規模について は，7割以上が40年以内を選択しており，また，30年以 内の氾濫確率については，6割以上が30\%以上の確率を 


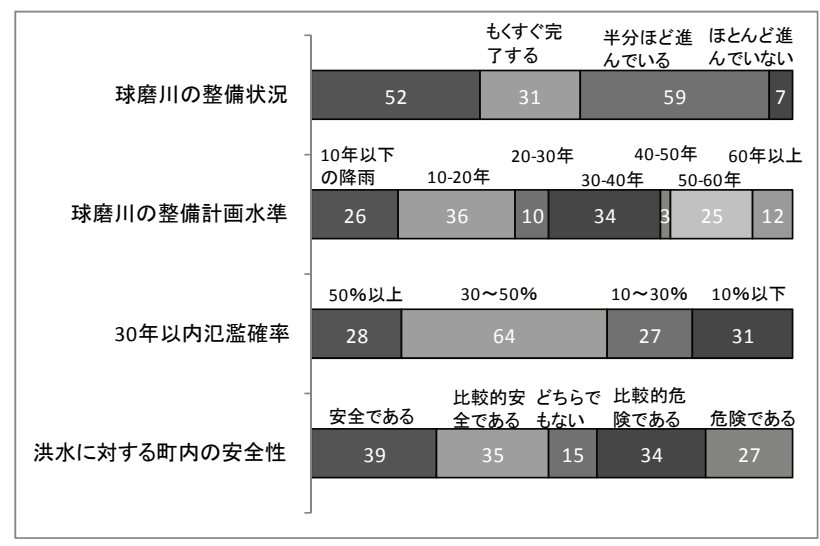

図-5 河川の整備状況と洪水発生に対する意識

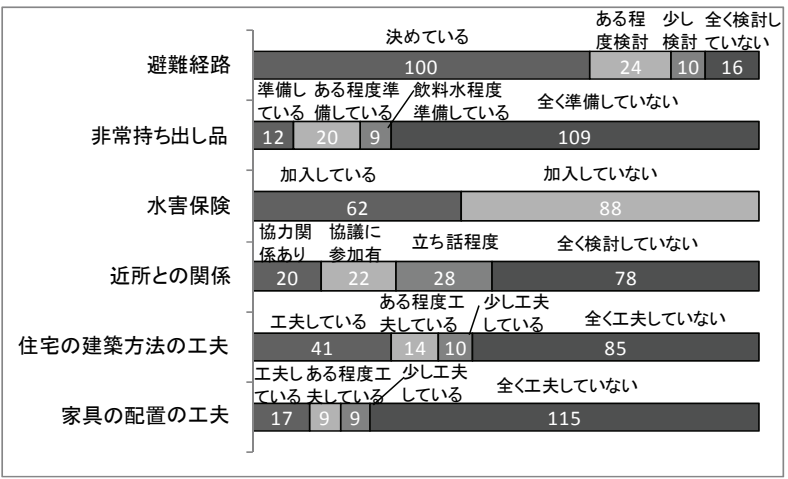

図-6 住民の洪水への備えの現状

選択している．以上の回答から，回答者は球磨川の整備 状況や水準に関する知識がそしいが，現在の河川状況を 考慮した洪水発生への認識はあるようである.

一方で，洪水が発生した場合の町内の安全性について は，「比較的危険である」もしくは「危険である」と回 答しているのは，4割程度である．球磨川が汇濫した場 合，対象地域の寸べての世帯が何らかの浸水被害を受け るが，表-3に示したように浸水すると回答しているのは 4割程度であり，この結果と対応している。このように 洪水発生時の危険性について，回答者は楽観的である.

次に，回答者の洪水への備えの現状を図-6に示す．避 難経路については，大部分の回答者が，「決めている」 か「検討している」と回答している，しかしながら，非 常持ち出し品については，7割以上が「全く準備してい ない」状況である．また，水害保険については，4割が 加入している. 洪水時の近所との関係については，事前 に協力体制を築いているのは1割超である．住宅の建築 については, 半数以上が洪水に対して「全く工夫してい ない」，また，家具の配置についても，7割以上が「全 く工夫していない」と回答している.

以上の事前アンケート調查結果から, 対象地域は球磨 川による水害リスクが高い地域であり，住民は球磨川の 汇濫の可能性については認識しているが，自身の被災に ついては楽観的であり，個人や地域で十分な洪水への備

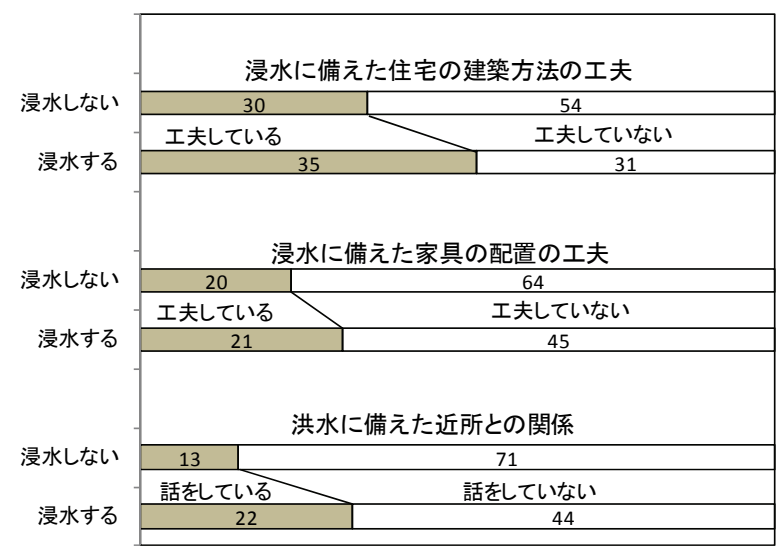

図-7 住民の浸水想定と洪水対策

表-4 観測変数の設定

\begin{tabular}{|c|c|}
\hline 観測変数 & 観測変数の設定 \\
\hline $\begin{array}{l}\text { 河川整備水準の } \\
\text { 認識 }\end{array}$ & $\begin{array}{l}\text { 整備完了: } 0, \text { もうすぐ整備完了: 1, } \\
\text { 半分ほど整備 : } 2, \text { ほとんど整備が進ん } \\
\text { でいない: }\end{array}$ \\
\hline $\begin{array}{l}\text { 洪水ハザードマ } \\
\text { ップの理解 }\end{array}$ & 理解していない：0, している：1 \\
\hline $\begin{array}{l}\text { 30年氾濫確率の } \\
\text { 認識 }\end{array}$ & $\begin{array}{l}\text { 10\%以下: } 0, \quad 10 \sim 30 \%: 1,30 \sim 50 \%: \\
2,50 \% \text { : }: 3\end{array}$ \\
\hline $\begin{array}{l}\text { 洪水に対する危 } \\
\text { 険性の認識 }\end{array}$ & $\begin{array}{l}\text { 安全である:-2, 比較的安全である：- } \\
1 \text {, どちらでもない: } 0 \text { ，比較的危険で } \\
\text { ある }: 1 \text {, 危険である }: 2\end{array}$ \\
\hline 浸水への認識 & 浸水しない: 0, 浸水する $: 1$ \\
\hline 建築方法の工夫 & 工夫していない: 0, している : 1 \\
\hline 家具配置の工夫 & 工夫していない: 0, している : 1 \\
\hline $\begin{array}{l}\text { 洪水について近 } \\
\text { 所との話合 }\end{array}$ & 0 \\
\hline
\end{tabular}

えが図られていないことが分かった.

\section{（3）洪水への備えの意識構造分析}

前節で示したように対象地域の住民の洪水への備えは 十分であるとは言えない，そこで，本節では洪水への備 えに関する意識構造を分析し，備えを促すにはどのよう にすべきかを検討する.

球磨川汇濫時に，住宅が「浸水する」と想定するか,

「浸水しない」と想定するかで，住民の洪水への備えに 違いがあるかを見るため，建築方法の工夫，家具の配置 の工夫，近所との関係について，「浸水する」と「浸水 しない」別に集計したものを図-7に示す。「浸水する」 と想定している回答者の世帯の方が，各項目において備 えを行っている割合が明らかに高い。このように，地域 の洪水に対する危険性の認識が高まれば，洪水への備え が向上すると考えられる. また，洪水に対する危険度の 認知は，その地域での洪水発生の認知の高さに依存する だろう。そこで，洪水への備えが，上述のような意識構 造にあるかを検証するため，「洪水への備え」に関する 因果構造モデルを共分散構造分析により推定する.なお, 観測変数には, アンケート調査票の項目のうち表-4に示 す項目を用いる.

「洪水への備え」に関する因果構造モデルのパス図を 
図-8に示す，潜在変数「洪水の認知」は，河川整備の水 準の認識や洪水ハザードマップの理解，30年氾濫確率の 認識といった3項目の観測変数により構築され，この

「洪水の認知」が潜在変数「危険度の評価」に影響し, そしてさらに「危険度の評価」が潜在変数「洪水への備 え」に影響していると仮定する。

「危険度の評価」は，洪水に対する危険性の認識や浸 水への認識といった観測変数の背後に存在すると仮定し た構成概念であり，また，「洪水への備え」は，洪水に 対する住宅の建築方法の工夫や家具の配置の工夫, 近所 との関係の背後に存在すると仮定した構成概念である.

表-5にパス係数の推定結果を示す. 図-8のパス図の観 測外生変数間のパスに示されているのは相関係数であり, また, 単方向の各パスに示されている数值は標準化され たパス係数, 各内生変数に示されているのは重相関係数 の平方である.このモデルの適合度指標（GFI）は0.973 であり, 残差平方平均平方根（RMR）は0.018であるこ とから「洪水への備え」の因果構造によく適合したモデ ルが得られていると言える. 一方, 構成概念の設定と観 測変数の選択については，表-5に示すように，「洪水へ の備え」から「洪水について近所との話合」のパス係数 を除けばすべてが有意水準 $5 \%$ の検定に対して有意であ る.したがって，「洪水の認知」が「危険度の評価」に 影響し, そして「洪水への備え」に影響していると考え て問題はない，以上のことから，「河川整備水準の認 識」や「洪水ハザードマップの理解」，「30年汇濫確率 の認識」を向上させれば，「洪水への備え」が向上する ことが期待される.

次に, 洪水ハザードマップの記述方法を工夫する上で, 「洪水ハザードマップの理解」に関する項目を探る。洪 水ハザードマップを見たことがあると回答した人に対し， マップの評価に関する10 項目について「全くそう思わ ない：1」から「非常にそう思う：5」の5段階でマップ を評価してもらった，その内訳は，使いやすさに関する もの 3 項目, わかりや寸さに関するもの 4 項目, 記載内 容に関するもの3項目より構成されている.
住民の洪水ハザードマップの理解度とマップの評価の 関係を検討するために，「洪水ハザードマップの内容を 理解しているグループ」と「洪水ハザードマップの内容 が理解できなかったグループ」別に評価レベルの平均值 を算出した. その結果を表-6 に示寸.

使いや寸さに関寸る項目では，洪水ハザードマップの 内容の理解度が異なるグループ間で評価レベルに有意な 差は見られない，一方，わかりやすさに関する項目では 3 項目全てに有意な差が見られ, 洪水ハザードマップの 目的のわかりやすさが，また記載内容に関する項目では 内容を理解しているグループで評価レベルが高くなって いる. したがって, 洪水ハザードマップの理解を向上さ せるには，住民が洪水ハザードマップの内容を「目的が 納得できる」, 「内容が正確」, および「内容が信頼で きる」と思えるように，記載内容を工夫する必要がある.

\section{4. 水害リスク情報の提供方法と意識}

\section{（1）提供情報}

前章の結果「内容が正確」であることを考慮して，洪

表-5 因果構造モデルのパス係数の推定結果

\begin{tabular}{|c|c|c|}
\hline パス & 推定值 & $\mathrm{t}$ 值 \\
\hline 洪水の認知〔河川整備の水準の認識 & 0.531 & - \\
\hline 洪水の認知〔洪水ハザードマップの理解 & 0.445 & $2.278^{*}$ \\
\hline 洪水の認知〔 -30 年汇濫確率の認識 & 0.628 & $2.482 * *$ \\
\hline 危険度の評価〔洪水の認知 & 0.625 & $2.858 * *$ \\
\hline 洪水に対する危険性の認識〔危険度の評価 & 0.714 & $3.874 * *$ \\
\hline 浸水への認識〔危険度の評価 & 0.469 & - \\
\hline 洪水への備えせ危険度の評価 & 0.645 & $2.007^{*}$ \\
\hline 建築方法の工夫〔洪水への備え & 0.321 & - \\
\hline 家具の配置の工夫〔洪水への備え & 0.479 & $1.935^{*}$ \\
\hline 洪水について近所との話合〔洪水への備え & 0.216 & 1.438 \\
\hline 適合度指標 $(\mathrm{GFI})$ & \multicolumn{2}{|c|}{ 残差平方平均平方根(RMR) } \\
\hline 0.973 & \multicolumn{2}{|l|}{0.018} \\
\hline
\end{tabular}

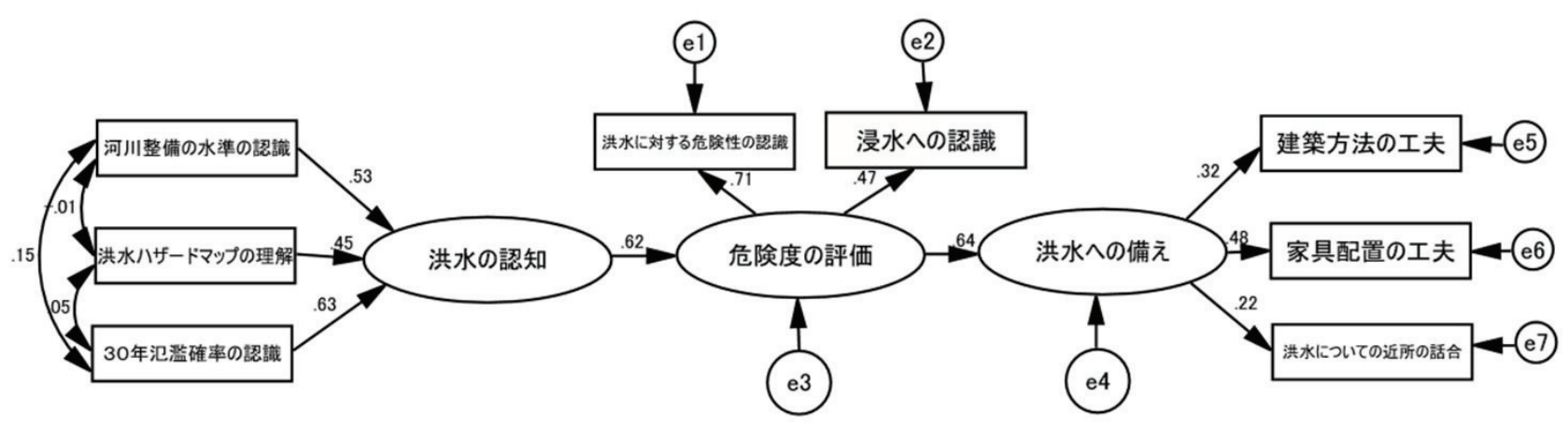

図-8 洪水への備えの因果構造モデル 
表-6＼cjkstart洪水ハザードマップの住民の評価と理解度

\begin{tabular}{|c|c|c|c|c|c|c|c|c|c|c|}
\hline & \multicolumn{3}{|c|}{ 使いやすさ } & \multicolumn{4}{|c|}{ わかりさすさ } & \multicolumn{3}{|c|}{ 記述内容 } \\
\hline & $\begin{array}{l}\text { 保 } \\
\text { 管 } \\
\text { や } \\
\text { 孪 } \\
\text { さ }\end{array}$ & $\begin{array}{l}\text { 壁 } \\
\text { 貼 } \\
\text { や } \\
\text { 严 } \\
\text { さ }\end{array}$ & $\begin{array}{l}\text { 持 } \\
\text { 出 } \\
\text { 出 } \\
\text { や } \\
\text { 亲 } \\
\text { さ }\end{array}$ & $\begin{array}{l}\text { 表 } \\
\text { 題 } \\
\text { お } \\
\text { か } \\
\text { り } \\
や \\
\text { す } \\
\text { w }\end{array}$ & 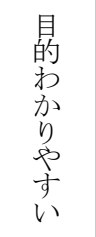 & $\begin{array}{l}\text { 内 } \\
\text { 容 } \\
わ \\
\text { 力 } \\
\text { り } \\
\text { や } \\
\text { す } \\
\text { w }\end{array}$ & $\begin{array}{l}\text { 見 } \\
\text { や } \\
\text { す } \\
\text { 心 }\end{array}$ & $\begin{array}{l}\text { 貝 } \\
\text { 的 } \\
\text { 得 } \\
\text { 点 } \\
\text { る } \\
\text { る }\end{array}$ & $\begin{array}{l}\text { 内 } \\
\text { 容 } \\
\text { 正 } \\
\text { 確 }\end{array}$ & $\begin{array}{l}\text { 内 } \\
\text { 容 } \\
\text { 信 } \\
\text { 頼 } \\
\text { き } \\
\text { る }\end{array}$ \\
\hline 全体（N=73） & 3.52 & 3.01 & 3.47 & 3.52 & 3.88 & 3.56 & 3.51 & 3.77 & 3.56 & 3.56 \\
\hline 内容を理解しているグループ（N=45） & 3.58 & 2.98 & 3.53 & 3.53 & 4.04 & 3.60 & 3.58 & 4.02 & 3.76 & 3.84 \\
\hline 内容を理解できなかったグループ（N=28） & 3.43 & 3.07 & 3.36 & 3.50 & 3.61 & 3.50 & 3.39 & 3.36 & 3.25 & 3.11 \\
\hline t值（両側検定，** : $1 \%$ 有意，* $: 5 \%$ 有意） & 0.61 & -0.33 & 0.62 & 0.16 & $2.20^{*}$ & 0.39 & 0.70 & $2.57 *$ & $2.23 *$ & $2.87 * *$ \\
\hline
\end{tabular}

水ハザードマップの想定条件の理解を図るために，図-9 に示すように「80年に1度の大雨を想定しています。」 を強調した. また, 洪水ハザードマップの他に洪水ハザ ードマップに記載されている情報と同等の内容を出来る 限り反映した水害リスク情報を 2 種類作成した。 なお， 2 種類とも洪水リスク情報提供の目的が明確になるよう避 難場所の情報が目立つように記述した。

作成した2種類の水害リスク情報のうち1つは，洪水の 発生確率に着目した水害リスク情報である。洪水ハザー ドマップの想定条件の説明として，「○年に1度起こる 規模の降雨量を対象としています。」等の記述が多くみ られる。本研究では，上述の「80年に1度起こる」を図10に示すように「30年以内に発生する確率はおよそ $30 \%$ 超」との表現に変えた水害リスク情報も提供する．なお， 30年という期間は地震調查研究推進本部政策委員会の報 告書 ${ }^{13)}$ に拠る.

もう1つは，水害に遭う被災者数を他の災害や事故等 の被災者数と比較した情報である。これは中谷内氏が提 案する「リスクのモノサシ」 ${ }^{14)}$ である. 水害の発生頻度 は交通事故や火事などに比べかなり低いが，発生した場 合の被害額ははるかに大きい.また，水害は被害額が大 きいだけでなく，被災者の数も多くなる．このことを示 寸ために，人口十万人当たり 1 年間の水害の被災者数だ けでなく, 他の災害や事故などの被災者数も比較情報と して同時に掲載する. 図-11に示すようにアンケート調 查を実施する際には，これらの情報と併せて「80年に1 度の大雨を想定しています。」との表現での水害リスク 情報および避難場所の情報を提供する.

\section{(2) 水害への意識の変化}

ここでは，「洪水ハザードマップ」，「30年確率表 記」および「リスクのモノサシ」で表現した水害リスク 情報を提示して「水害への意識」の変化を見ていく．ア ンケートの各項目に対する事前調査時の回答分布にグル ープ間で有意な差は見られなかったので，事前調査の回 答分布を基準に「水害への意識」の変化を見ていく.

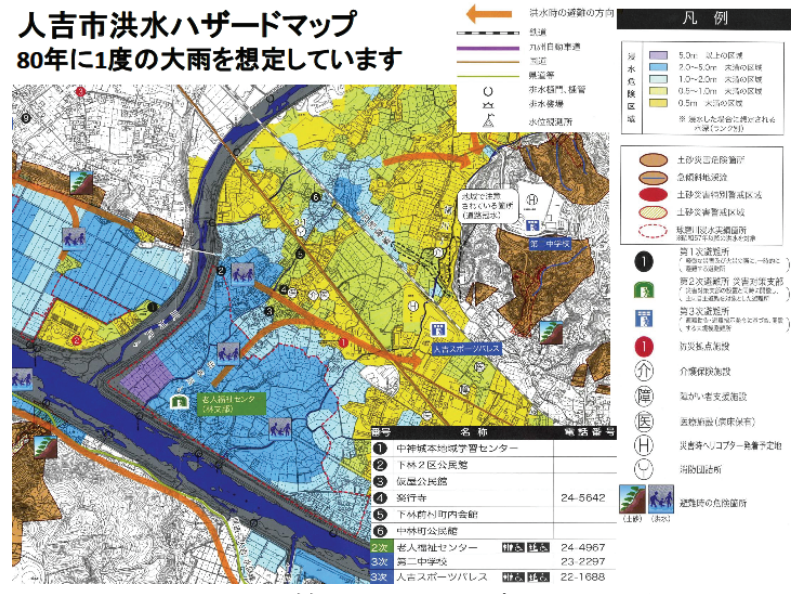

図-9 提供情報1 : 洪水ハザードマップ

球磨川は80年に1度の大雨を計画して作られています \(まだ整借は完了していません)

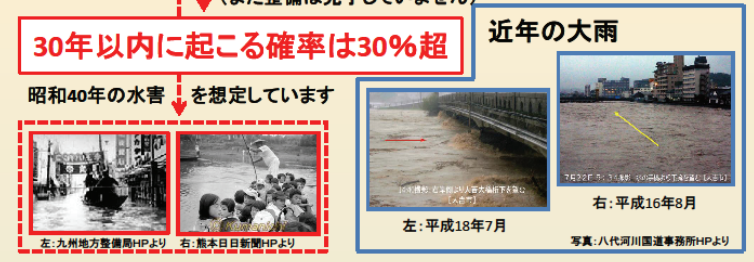

レ大雨が降り、避難が必要な場合の避難所です

\begin{tabular}{|c|c|c|c|}
\hline 趡期場所 & 第1避期埸所 & 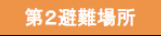 & 第3造期場所 \\
\hline 温泉町 & 楽行寺 & 老人福祉センター & 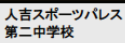 \\
\hline 下林2区 & 下林町 2 区公民館 & 老人福祉センター & $\begin{array}{l}\text { 人吉スポーヅイ゚スス } \\
\text { 第二中学校 }\end{array}$ \\
\hline 下林仮屋地区 & 下林町仮屋公民館 & 老人福祉センター & 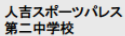 \\
\hline
\end{tabular}

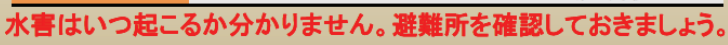

図-10 提供情報 $2: 30$ 年確率表記

水害は火災や地震よりも被害に遭う人が多い災害です

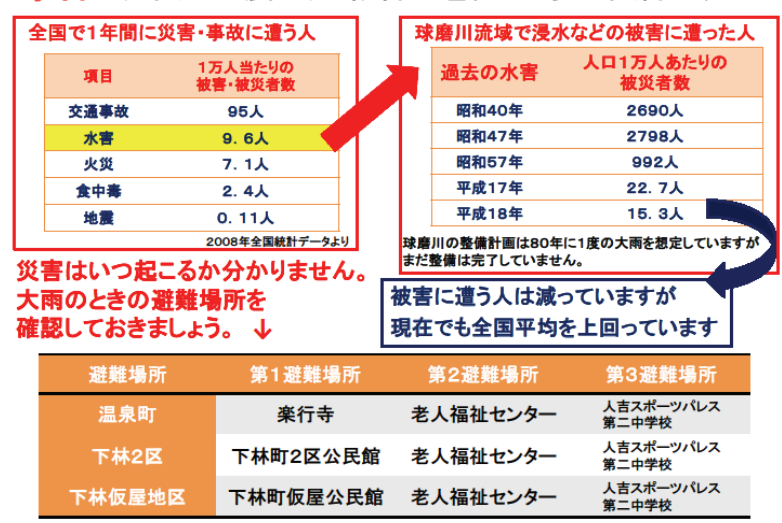

図-11 提供情報3：リスクのモノサシ 


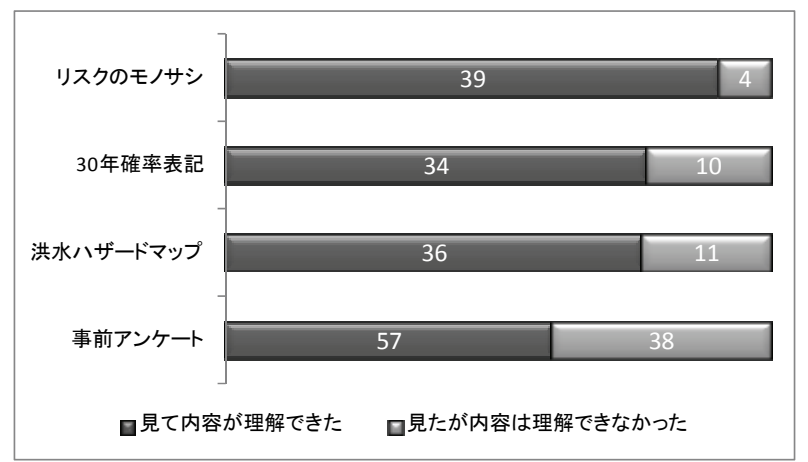

図-12 提供情報の理解度

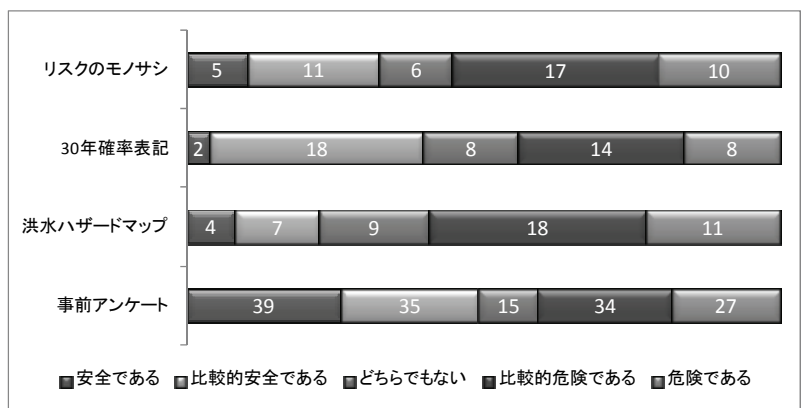

図-13 洪水に対寸る町内の安全性の意識

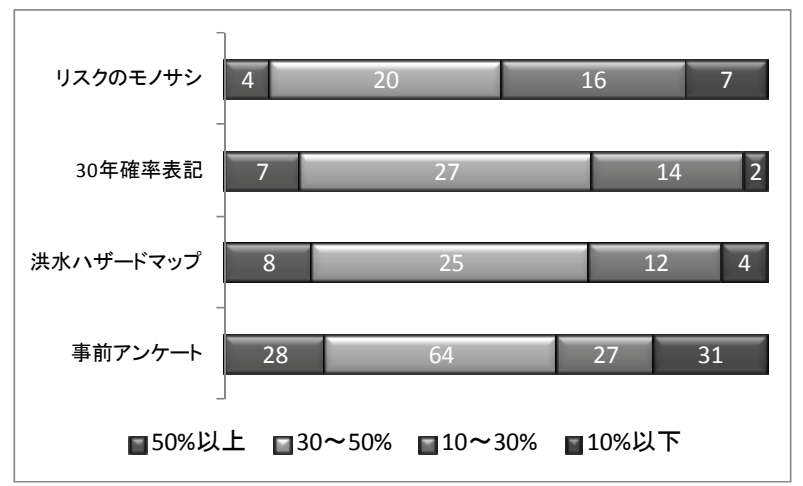

図-14 30年以内の汇濫確率

表-7 情報提供後の回答者の想定浸水深

\begin{tabular}{|c|c|c|c|c|c|c|c|c|}
\hline \multirow{3}{*}{ 公 } & \multicolumn{8}{|c|}{ アンケート回答者の想定浸水深 } \\
\hline & & 浸水しない & $0.5 \mathrm{~m}$ 以下 & $0.5-1.0 \mathrm{~m}$ & 1.0-2.0m & $2.0-5.0 \mathrm{~m}$ & 5.0m以上 & 計 \\
\hline & 浸水しない & 0 & 0 & 0 & 0 & 0 & 0 & 0 \\
\hline & $0.5 \mathrm{~m}$ 以下 & 1 & 3 & 0 & 0 & 0 & 0 & 4 \\
\hline & $0.5-1.0 \mathrm{~m}$ & 2 & 3 & 1 & 2 & 0 & 0 & 8 \\
\hline & 1.02-2.0m & 10 & 16 & 3 & 4 & 1 & 1 & 35 \\
\hline & $20.5 .0 \mathrm{~m}$ & 17 & 26 & 32 & 15 & 8 & 3 & 101 \\
\hline & 5.0m以上 & 0 & 0 & 0 & 0 & 0 & 0 & 0 \\
\hline & 計 & 30 & 48 & 36 & 21 & 9 & 4 & 148 \\
\hline
\end{tabular}

図-12に提供情報の理解度を示寸，提供情報の理解度 が高かったのは, リスクのモノサシによるものであった これは，空間的な情報が含まれる「洪水ハザードマッ プ」や一般になじみ難い確率表現を含んだ「30年確率表 記」に比べて，「リスクのモノサシ」での表現は, よく 見聞きする他の事象との比較で分かりやすかったことが 挙げられよう. 図-13に洪水に対寸る町内の安全性の意 識を示す。「リスクのモノサシ」の場合, 事前調查結果 と比較して「比較的危険である」と「危険である」を選 択している割合が増加している。 しかしながら，図-14 に示す 30 年以内の氾濫確率については, 事前調查結果と
比較して $30 \%$ 以下の確率を選択して回答者の割合が増加 している. したがって,「リスクのモノサシ」による表 現は，理解が容易であることにより，洪水が発生した場 合の危険性の認識を向上させているが，洪水発生一の切 迫感は醸成してしないことが分かる，逆に，「30年確率 表記」による表現は，洪水発生一の切迫感は醸成してい るが，洪水が発生した場合の危険性の認識は向上させて いないことが分かる．それに対し「洪水八ザードマッ プ」は, 洪水が発生した場合の危険性の認識を向上させ, また, 洪水発生一の切迫感も醸成している。これは,

「洪水ハザードマップ」の情報は空間認識ができ，また， 情報量が豊富であることに寄るものであろう.

これらの情報提供後に再度回答者自身の想定浸水深に ついても尋ねた。 情報提供後の洪水ハザードマップ上の 想定浸水深と回答者自身の想定浸水深の関係を表-7に示 寸. 回答者の洪水八ザードマップの内容の理解度が上が ったにも関わらず，依然として左下側の組み合わせに回 答が集中しており，大部分の世帯が自身の居住地点を安 全と考えていることが分かる. これは，情報の提供によ って地域の洪水に対する危険性は分かるが，自分のとこ ろは大丈夫といった正常化の偏見が，情報提供後も存在 していることを示す. しかし, 表-3と比較すると浸水し ないとの回答が84から30に減少したことからも分かるよ うに, 組み合わせの分布が対角側にシフトしており, 居 住地点の浸水意識の醸成が図られていることが分かる.

\section{(3)「洪水への備え」の変化}

前項の結果は, 図-8の「洪水への備え」の因果構造モ デルにしたがえば，「洪水の認知」が進み「危険度の評 価」が向上していることになる，したがって，それらを 通じて「洪水への備え」が変化することが予測される. 備えを行うためには時間と費用を伴うため, ここでは 「洪水への備え」に関係する項目について，今後備えを 行うかどうかを尋㸚た. 結果を図-15から図-18に示寸.

非常持ち出し品の準備と家具の配置の工夫については, どの表現の水害リスク情報の場合も変化傾向は変わらな かった. 非常持ち出し品の準備については, 飲料水程度 の簡単なものの準備はしておこうとの意識が醸成され, 家具の配置の工夫については，「工夫をしない」との回 答がどの表現の場合にも30\%程度あったが，概初何らか の工夫をしようとする意識が醸成されている. 建築方法 の工夫についても，概衱何らかの工夫をしようとする意 識が醸成されているが，「30年確率表記」の場合に前述 したように洪水が発生した場合の危険性の認識を向上さ せていないため，「工夫しない」との回答が多かったよ うである。それに対し「近所との関係」については,

「検討せず」との回答が洪水ハザードマップを提示した 場合に若干多かった，洪水ハザードマップは，掲載され 
ている情報量が多いため, 理解出来れば近所との関係性 を深めなくても，自律的な避難対応が可能と判断したの かもしれない.

以上のように，洪水に関する各情報提示で地域におけ る「洪水の認知」をさせ，居住地域の「危険度の評価」 を向上させることで「洪水への備え」が進む可能性が検 証された. しかしながら，提示情報の理解や地域の危険 性の認識, 備えの意識の醸成などに対する効果に, 各表 現方法に一長一短があることも明らかになった。 そこで, 各表現の水害リスク情報を組夕合わせることで，それら の特性を活かし，洪水ハザードマップの内容の理解度や 信頼度を向上させることが出来るか検証した.

組み合わせは，情報量が一番豊富な「洪水八ザードマ ップ」に「30年確率表記」を加えたものと「リスクのモ ノサシ」を加えたものの2種類である. 先のアンケート

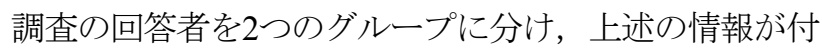
加された 2 種類の洪水ハザードマップのうち一方だけを， 各グループに提示した．そして，洪水八ザードマップの 内容が理解できるかと洪水八ザードマップに記載された 情報が信頼できるかについて尋ねた。 その結果を図-19 および図-20に示す，事前調査や洪水ハザードマップの みを見せた場合の理解度は図-12に示寸とおりであり， また，事前調查時に洪水八ザードマップを見たことがあ ると回答した人で信頼していると回答した割合は約 $60 \%$ であった．したがって，情報を付加した洪水八ザードマ ップに対する理解度と信頼度は，図-19および図-20より 双方ともそれらより高いものとなっている．内容は違う が2度目の水害リスク情報の提示であり，その分は割り 引いて評価する必要があるが，情報を組久合わせること で洪水ハザードマップの内容の理解度や信頼度が向上す ることが分かった．また，「洪水ハザードマップ」に

「30年確率表記」を加えたものより，「洪水八ザードマ ップ」に「リスクのモノサシ」を加えたものの方が，洪 水ハザードマップの内容の理解度および信頼度の双方が 高いとの結果となった.

\section{5. おわりに}

本研究では, 熊本県人吉市の水害リスクの高い地域の 世帯を対象に，水害リスクの認知や洪水への備えを促す 水害リスク情報の表現方法を検討した．まず，水害への 意識調査データを用いた「洪水への備え」に関寸る因果 構造モデルから，「洪水の認知」が「危険度の評価」に 影響し，そして「洪水への備え」に影響していることを 明らかした. また，洪水ハザードマップの評価から理解 を向上させるには，「目的が納得できる」，「内容が正 確」，「内容が信頼できる」と住民が思えるように記載 内容を工夫する必要があることが明らかになった。

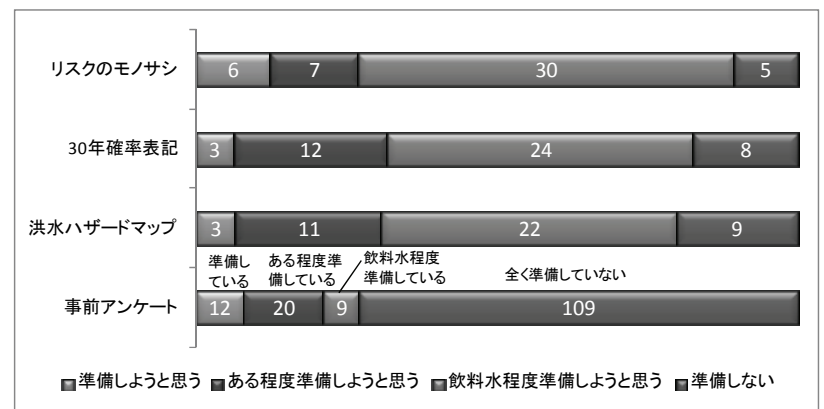

図-15 非常持ち出し品の準備

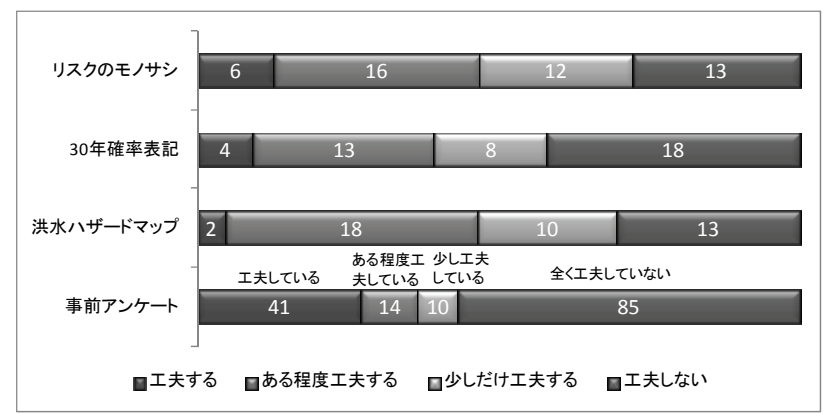

図-16 建築方法の工夫

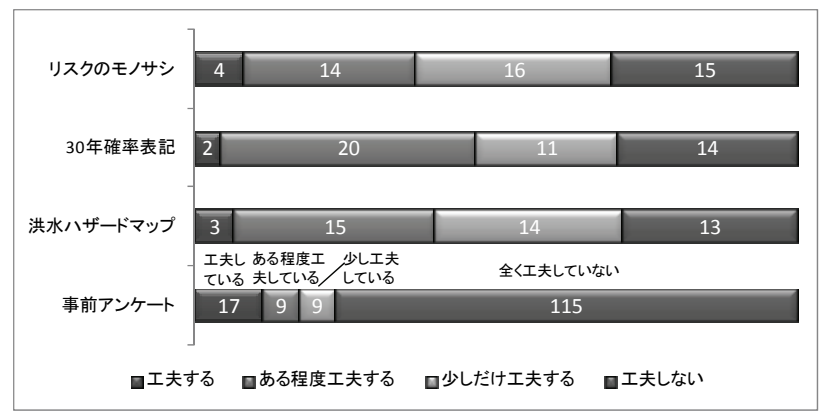

図-17 家具の配置の工夫

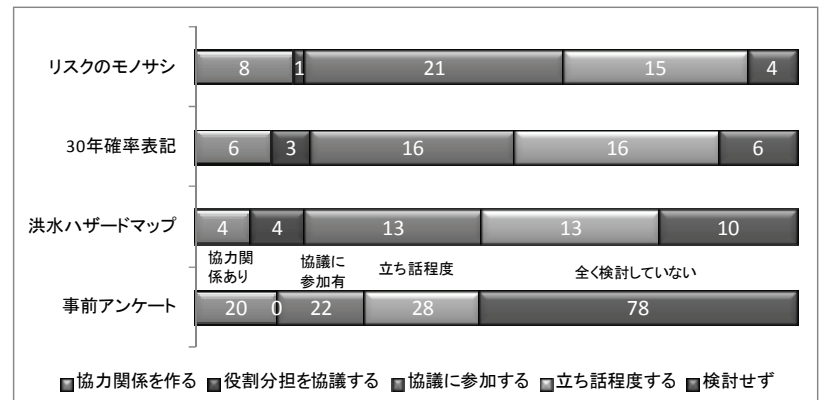

図-18 近所との関係

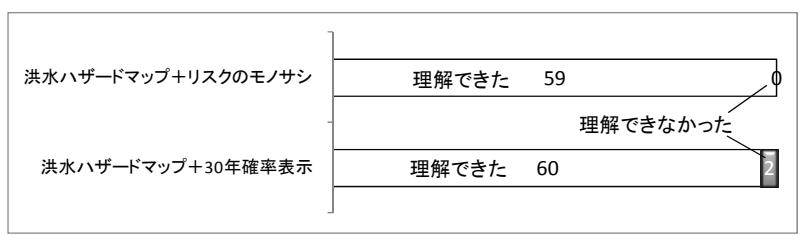

図-19 提示情報の理解度

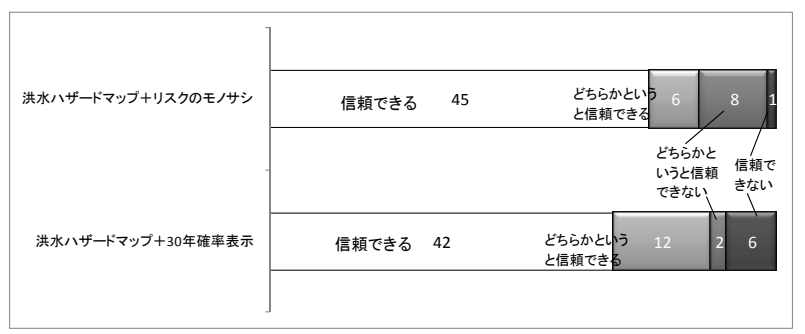

図-20＼cjkstart提示情報の信頼度 
そこで，洪水ハザードマップの想定条件の理解を図る ために，「80年に1度の大雨を想定しています。」を強 調した洪水ハザードマップを作製した。また，「30年確 率表記」および「リスクのモノサシ」による水害リスク 情報を作成した，対象地域の世帯に，それら3つの異な る表現の水害リスク情報を提示し，水害リスク認知や洪 水への備えの意識が事前調査から変化するかを検証した. その結果，各表現の特性に応じて水害リスク認知や備え が促されることが分かった。ささらに，各表現方法の特性 を活かすために，掲載情報が一番豊富な「洪水ハザード マップ」をベースに，「30年確率表記」と「リスクのモ ノサシ」を加えた 2 種類の水害リスク情報を作成し，対 象世帯に提示した. その結果，洪水ハザードマップの理 解度と信頼度が向上した，特に，それ自身の理解が高か った「リスクのモノサシ」を「洪水ハザードマップ」に 付加した場合の方が, 理解度と信頼度の向上が大きかっ た.

以上のことから, 表現方法の工夫やその組み合わせに より，地域の水害リスクの認知や洪水への備えの意識を 醸成することが可能であることが分かった，一方で，正 常化の偏見が，災害リスク情報提供後もあることが分か った。したがって，災害への備えを促進するには， PDCAサイクルに基づいた自主防災活動等の中で，災害 リスク情報の提供や避難訓練を繰り返し行っていく必要 があるだろう。また, 繰り返し提供する災害リスク情報 の内容を検討する必要もある。

本研究の結果は，提供された災害リスク情報を見たと の条件の下でのものである。図-4に示したように4割の 世帯が洪水ハザードマップを見ていない，地域全体の防 災力の向上を図るためには，住民の災害情報へのアクセ スへのハードルを如何に低くするかが今後の課題となる.

\section{参考文献}

1) 片田敏孝, 児玉真, 佐伯博人 : 洪水ハザードマップ の住民認知とその促進策に関する研究, 水工学論文 集, 第 48 巻, pp.433-438, 2004.
2) 藤井聡, 竹村和久, 吉川肇子, 横松宗太 : 災害リス ク認知とコミュニケーション, 土木計画学研究発表 会・講演集, Vol.27, CD-ROM (SS3), 2003.

3) 片田敏孝, 淺田純作，及川康：過去の洪水に関する 学校教育と伝承が住民の災害意識と対応行動に与え る影響, 水工学論文集, 44 巻, pp.325-330, 2000.

4) 山浦浩太 : 治水対策が住民の水害リスク認知に与え る影響〜利根川水系の真間川流域を対象に〜，筑波 大学大学院博士課程 システム情報工学研究科修士論 文，2003.

5) 元吉忠寛, 高尾堅司, 池田三郎：水害リスクの受容 に影響を及ぼす要因, 社会心理学研究, 第 20 巻第 1 号, pp.58-67, 2004.

6) 梅本通孝：住民の災害リスク認知に関する研究一高 知県高知市と茨城県日立市における比較一, 地域安 全学会論文集, No.8, pp.297-306, 2006.

7) 片田敏孝, 木村秀治, 児玉 真 : 災害リスク・コミュ ニケーションのための洪水ハザードマップのあり方 に関する研究, 土木学会論文集 D, Vol.63, No.4, pp.498-508, 2007.

8) 松井良太 : 洪水ハザードマップの記載内容に関する 研究, 信州大学工学部社会開発工学科環境都市コー ス卒業論文， 2008 .

9) 片田敏孝, 木村秀治, 児玉真, 及川康 : 災害リス ク・コミュニケーションツールとしてみた洪水ハザ ードマップの可能性, 土木計画学研究講演論文集, Vol.35, CD-ROM (234), 2007.

10) 天王嘉乃, 山崎祐輔, 高木朗義 : 地域住民の洪水リ スク認知度と自主防災行動とのズレ，土木計画学研 究・論文集, Vol.24, pp.299-306, 2007.

11) 山崎祐輔, 天王嘉乃, 高木朗義 : 洪水災害に対する 住民の備えとその促進策の検討, 土木計画学研究・ 論文集，Vol.25, pp.85-92, 2008.

12）国土交通省九州地方整備局八代河川国道事務所 : 球 磨川水系河川整備基本方針の内容及び同方針の審議 経過について, くまがわ・明日の川づくり報告会資 料, 2007 .

13）地震調查研究推進本部政策委員会成果を社会に活か す部会：地震調查研究推進本部政策委員会成果を社 会に活かす部会報告一地震動予測地図を防災対策等 に活用していくために一, 2005.

14) 中谷内一也：リスクのモノサシ, 日本放送出版協会, 2006.

(2012. 2. 25 受付)

\section{STUDY ON AN EXPRESSION OF FLOOD RISK INFORMATION}

\section{Ryuji KAKIMOTO and Yasushi ENOMURA}

This paper aims to study an expression of flood risk information owing to prompt recognition of flood risk and preparedness for flood. First, an attitude survey of flood was done in high risk area of flood and covariance structure analysis and evaluation of flood hazard map were executed. According to the result, three kinds of flood risk information, flood hazard map, probability expression of return period, and expression of risk measure, were made and were shown to the residents. As a result, it was made clear that recognition of flood risk and preparedness for flood were promoted according to a characteristic of each expression. Furthermore, probability expression of return period or expression of risk measure was added to flood hazard map to make use of a characteristic of each expression. Consequently, understanding and reliability of flood hazard map were improved. 